\title{
Hypofractionation for Prostate Cancer: Where do we go next?
}

\author{
Dilip D Panjwani* \\ Director, Compassionate Cancer Centre Pvt. Ltd, India \\ Submission: December 06, 2019; Published: December 16, 2019 \\ *Corresponding author: Dilip D Panjwani, Director, Compassionate Cancer Centre Pvt. Ltd, India
}

Keywords: Hypofractionated radiotherapy; Toxicities, Acceleration; Protocols; Sensitivity; Tissues

\section{Short Communication}

Hypofractionated radiotherapy for localized prostate cancer has recently been strongly recommended in evidence-based guidelines jointly published by ASTRO, ASCO and AUA [1]. While it has obvious advantages in cost and convenience, there remains a concern about associated acute and late toxicities: Two randomized controlled trials-HYPRO [2] and RTOG 0415 [3]-did identify a somewhat increased risk of late toxicity, and several, CHHiP [4], PROFIT [5], HYPRO and Fox Chase [6], all found increased risk of acute GI toxicity with hypofractionation. These concerns are greater when ultra-hypofractionation is used [1]. In order to reduce the acute and late toxicities, our group at Grand River Hospital, Kitchener, Ontario, back in 2006, started a Phase II trial [7] in which we stretched the overall treatment time (OTT) to be the same as that in dose escalated conventional radiotherapy, and showed that both acute and late side-effects were very low with this intervention. Subsequently [8] have shown in the PATRIOT trial that stretching the OTT is indeed beneficial, when tested in a randomized fashion.

In this review, the radiobiological basis of hypofractionation with stretching of OTT (which we call 'Pure Hypofractionation', as it is free of the inherent acceleration seen in most hypofractionation protocols) and how a large accurately designed randomized trial could tell us whether we can improve the results of hypofractionation for prostate cancer using pure hypofractionation, will be discussed. The two radiobiologic hallmarks of prostate cancer are 'high fractionation sensitivity' and 'slow repopulation'. The fractionation sensitivity is commonly expressed inversely as the alpha/beta ratio; for most cancers as well as for 'acute-reacting' tissues like skin and mucosa, fractionation of a particular dose of radiotherapy results in only a limited impairment of cell kill (low fractionation sensitivity and high alpha/beta ratio), while for prostate cancer and 'late-reacting' tissues like muscle \& bone, the cell-kill diminishes markedly with fractionation (high fractionation sensitivity and low alpha/beta ratio). Therefore, when hypofractionation is used, the total nominal dose required to 'cure' the prostate cancer is lower than the total nominal dose used in conventionally fractionated radiotherapy; this lower nominal dose produces a lower biologically equivalent dose (BED) for the organs at risk (e.g. which have a higher BED, as compared to that of prostate cancer of 1.5), as

$$
B E D=n d(1+d \div \alpha / \beta)
$$

(n=no. of fractions, $d=$ dose per fraction)

This should result in a therapeutic advantage, with lower acute and late side-effects with hypofractionation. Unfortunately, this hope of reducing toxicity with hypofractionation has not been borne out in the studies mentioned above. One reason for this could be that hypofractionation protocols have an inherent acceleration in them, as the overall treatment time (OTT) is shortened. Looking at the following elaborate formula for BED, which takes the OTT also in account, would explain why the acute side-effects of 'accelerated' hypofractionation would be worse:

$$
B E D=n d\left(1+\frac{d}{\alpha / \beta}\right)-\frac{\operatorname{Ln} 2\left(T-T_{k}\right)}{\alpha T_{p}}
$$

$\left(\mathrm{T}=0 \mathrm{TT}, \mathrm{T}_{\mathrm{k}}=\right.$ start time for repopulation, $\mathrm{T}_{\mathrm{p}}=$ potential doubling time)

The OTT affects the repopulation during treatment, which in turn affects cell-kill and acute toxicity. Thus, by accelerating we increase the BED to rectal and bladder mucosa, leading to not only the acute toxicity, but also the 'consequential' late toxicity, which is particularly important in the rectum. The corresponding increase in cell-kill to the prostate cancer is small, given that the potential doubling time of prostate cancer is measured in months (while that of rectal and bladder mucosa is measured in days). Therefore, eliminating the inherent acceleration seen in most hypofractionation protocols which have a shortened OTT would 
remove the above therapeutic disadvantage. We believe that a randomized clinical trial treating localized prostate cancer with pure hypofractionation consisting of $6000 \mathrm{cGy}$ in 20 fractions delivered over 8 weeks (every other working day) with the standard arm being 7800cGy in 39 fractions over 8 weeks, would help in clarifying whether this radiobiologic promise is borne out

\section{References}

1. Scott C, Karen H, Andrew DL, Mark K, Caroline P, et al. (2018) Hypofractionated Radiation Therapy for Localized Prostate Cancer: An ASTRO, ASCO, and AUA Evidence-Based Guideline. Journal of Clinical Oncology 36(34): 3411-3430.

2. Luca I, Ruud C, Wendimagegn G, Shafak A, Erik S, et al. (2016) Hypofractionated versus conventionally fractionated radiotherapy for patients with localised prostate cancer (HYPRO): final efficacy results from a randomised, multicentre, open-label, phase 3 trial. Lancet Oncol 17: 1061-1069.

3. Watkins BD, Pugh SL, Lee WR, Dignam JJ, Low D, et al. (2016) NRG Oncology/RTOG 0415, Phase 3 Noninferiority Study Comparing 2 Fractionation Schedules in Patients with Low-Risk Prostate Cancer:
Prostate-Specific Quality of Life Results. Int J Radiat Oncol Biol Phys 96S2-S3.

4. Anna W, Helen M, Isabel S, Vincent K, David B, et al. (2015) Hypofractionated radiotherapy versus conventionally fractionated radiotherapy for patients with intermediate-risk localised prostate cancer: 2-year patient-reported outcomes of the randomised, noninferiority, phase 3 CHHiP trial. Lancet Oncol 16(16): 1605-1616.

5. Charles N, Himu L, Chu-Shu G, Jarad MM, Stéphane S, et al. (2017) Randomized Trial of a Hypofractionated Radiation Regimen for the Treatment of Localized Prostate Cancer. J Clin Oncol 35: 1884-1890.

6. Alan P, Gail W, Eric MH, Robert P, Steven F, et al. (2013) Randomized Trial of Hypofractionated External-Beam Radiotherapy for Prostate Cancer. J Clin Oncol 31: 3860-3868.

7. Darin G, Dilip P, Robert FS, Michael L (2018) Phase II Trial of Pure Hypofractionated Radiotherapy in the Treatment of Localized Carcinoma of the Prostate. Cureus 10(10): e3435.

8. Harvey CQ, Aldrich O, Patrick C, William C, Hans T, et al. (2018) Onceweekly versus every-other-day stereotactic body radiotherapy in patients with prostate cancer (PATRIOT): A phase 2 randomized trial. Radiotherapy and Oncology 127(2): 206-212.

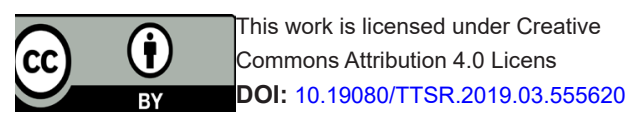

\section{Your next submission with Juniper Publishers will reach you the below assets}

- Quality Editorial service

- Swift Peer Review

- Reprints availability

- E-prints Service

- Manuscript Podcast for convenient understanding

- Global attainment for your research

- Manuscript accessibility in different formats

( Pdf, E-pub, Full Text, Audio)

- Unceasing customer service

Track the below URL for one-step submission

https://juniperpublishers.com/online-submission.php 